\title{
Menggugat Hukum yang Bias Gender
}

\author{
Zairin Harahap
}

\begin{abstract}
Law put women in inequitable position One of the reasons is strong patriarchy culture in our community up to this time. Such culture out women in weak and domestic position and the positioning is on the basis of destiny where gender issue is merely connoted with sex.
\end{abstract}

\section{Pendahuluan}

Banyak orang yang masih percaya atau bahkan sangat percaya bahwa apabila hukum diterapkan akan dapat memberikan perlindungan, kesejahteraan, kebenaran, persamaan, dan keadilan. Hukum juga dipercaya dapat dijadikan tempat dan alat untuk memperjuangkan hak-hak mereka (site of struggle). Namun, sesungguhnya apabila hukum ditinjau melalui paradigma kritis, maka persepsi arus umum (mainstream) yang cukup lama bertahan tanpa digoyang-goyangkan ini akan dipertanyakan, malahan akan ditolak. ${ }^{1}$

Di samping itu, akan terungkap bahwa hubungan antara hukum dan keadilan tidak begitu kausal sifatnya. Banyak sekali peraturan hukum yang tumpul, tidak mempan memotongmotong kesewenang-wenangan, tidak mampu menegakkan keadilan dan tidak mampu menampilkan dirinya sebagai pedoman yang harus diikuti dalam menyelesaikan berbagai kasus yang seharusnya bisa dijawab oleh hukum. Bahkan, banyak produk hukum yang lebih diwarnai oleh kepentingankepentingan politik pemegang kekuasaan dominan. ${ }^{2}$ Berbagai kepentingan tertentu akhimya dimenangkan dan terlindungi dalam rumusan hukum atau terjadi semacam politik dagang sapi, sehingga ketentuan-ketentuan hukum yang dirumuskan itu merupakan kompromi dari nilai-nilai yang diperjuangkan

'T.O. Ihromi, "Mengupayakan Kepekaan Jender dan Hukum: Contoh-contoh dari Berbagai Kelompok Masyarakat", dalam Smita Notosusanto dan EKristi Poerwandi (Penyunting), Perempuan dan Pemberdayaan, Diterbitkan oleh Program Studi Kajian Wanita Program Pasca Sarjana Universitas Indonesia Bekerjasama dengan Kompas dan Penerbit Obor, Jakarta, 1997, hlm. 173.

2Moh. Mahfud MD, 1998, Politik Hukum di indonesia (Jakarta: Penerbit LP3ES, 1998), him. 1. 
oleh golongan-golongan yang bertarung untuk térintegrasi ke dalam aturan-aturan yang hendak disusun. Dengan demikian, sejak awal, sejak dalam kandungan, atau bahkan sebelum lahir sesungguhnya hukum tersebut telah tidak memiliki rasa keadilan. Oleh karenanya, bagaimana mungkin, jika diterapkan (implementation) dan ditegakkan (law enforcement) dapat memeberikan rasa perlindungan, kesejahteraan, kebenaran, persamaan, dan keadilan?

Jika sudah diketahui bahwa hukum adalah hasil pergulatan kepentingan dan mencerminkan standar nilai yang dianut masyarakat pada saat diciptakan, maka seharusnya kita tidak menaruh kepercayaan yang begitu besar terhadap hukum. Apalagi bagi kaum perempuan, di mana nilai-nilai kultural yang berkaitan dengan seksualitas perempuan dan nilai-nilai yang mencerminkan ketidaksetaraan gender berpengaruh sangat besar dalam perumusan. Bahkan, pelaksanaan hukum mudah diduga telah menempatkan perempuan pada posisi yang tidak adil. Dalam kerangka inilah, harus dilakukan rekonstruksi terhadap hukum yang membatasi dan menindas gender, sehingga dengan begitu tidak akan mengakibatkan terjadinya. sebagaimana apa yang disebut oleh Ivan Illich sebagai matinya gender. ${ }^{3}$

Bähkan, banyak yang mempertanyakan keabsahan wacana tentang perempuan sebagai makhluk yang lemah, pasif, dan mempunyai orientasi lokal. Perempuan dalam berbagai kasus lebih mobil dibanding laki-laki, lebih aktif dalam berbagai aktivitas, dan terlibat langsung dalam proses pengambilan keputusan. Subordinasi perempuan, jangan-jangan hanya merupakan retorika, karena kesalahan representasi bahwa perempuan tersubordiansi dalam suatu struktur yang patriarkhal. ${ }^{4} \mathrm{Namun}$, ironisnya sebagian besar pekerjaan wanita itu baik yang dikerjakan di dalam rumah (misalnya; memasak, membersihkan rumah, manjaga rumah, mengasuh anak, dan memelihara ternak) maupun yang dilakukan di luar rumah (misalnya; berkébun, bertani, dan berjualan) tidak dihargai atau dihitung secara ekonomi. Sehingga, tetap saja laki-laki yang dipersepsikan sebagai tulang punggung ekonomi keluarga. Perempuan yang bekerja itu, posisinya tetap saja dipersepsikan sebagai membantu bukan pokok. Untuk sebagian masyarakat juga, masih memiliki semacam kepercayaan bahwa yang bekerja mencari nafkah adalah laki-laki, sehingga sebagian orang tua terkadang justru mengawinkan anak perempuannya dalam usia yang relatif dini agar anaknya itu secara ekonomi dapat terbantu kebutuhannya. Implikasi lebih lanjut adalah perempuan yang menikah di usia yang relatif tua dianggap tidak laku, dan seperangkat sebutan-sebutan yang minus lainnya. Kepercayaan-kepercayaan seperti sudah barang tentu telah menempatkan kaum perempuan pada posisi yang sangat lemah dan laki-laki pada posisi yang sangat kuat. Tak jarang pula, mereka yang kawin muda, kemudian harus bercerai. Setelah itu, pada umumnya kaum perempuanlah yang terbebani membesarkan anaknya.

\footnotetext{
${ }^{3} \mid$ van Illich, Matinya Gender, Cetakan Ketiga, (Yogyakarta: Penerbit Pustaka Pelajar, 2001)

4Iwan Abdullah, Seks, Gender, dan Reproduksi Kekuasaan, Penerbit Tarawang Press, (Yogyakarta, 2001), hlm. 26.
} 
Masyarakat kita bersifat patriarkhis atau merupakan masyarakat di mana pria dominan sifatnya, sehingga ketentuan-ketentuan hukum dalam proses penyușunannya banyak yang mengandung bias terhadap pria atau yang menjadi ukuran penentu adalah penilaian pria. ${ }^{5}$ Tata masyarakat patriarkhis seperti ini digugat kaum feminis, karena cenderung meminggirkan posisi perempuan. Perempuan cenderung diposisikan sebagai subordinat, dikotakkan ke dalam dunia domestik dan dibatasi haknya untuk masuk ke dunia publik, padahal perempuan dan laki-laki memiliki potensi sama dan karena itu seharusnya mempunyai hak yang sama. ${ }^{6}$ Ideologi patriarkhi merupakan salah satu variasi dari ideologi hegemoni, suatu ideologi yang membenarkan penguasaan satu kelompok terhadap kelompok lainnya. Dominasi kekuasaan seperti ini dapat terjadi antar kelompok berdasarkan jenis kelamin, agama, ras, atau kelas ekonomi. Ada tiga asumsi penting yang mendasari ideologi ini:

1. Kesepakatan-kesepakatan sosial sesungguhnya hanya menguntungkan kepentingan kelompok yang dominan cenderung dianggap mewakili kepentingan semua orang;

2. Ideologi hegemonis seperti ini merupakan bagian dari pemikiran sehari-hari, cenderung diterima apa adanya (taken for granted) sebagai sesuatu yang memang demikianlah semestinya;
3. Dengan mengabaikan kontradiksi yang sangat nyata antara kepentingan kelompok yang dominan dengan kelompok subordinat; ideologi seperti ini dianggap sebagai penjamin kohesi dan kerjasama sosial jika, tidak demikian, yang justru suatu konflik.

Lebih lanjut dikemukakan bahwa ketika hubungan antar individu didominasi oleh ideology hegemonis, kelompok yang tersubordinasi tidak mempunyai ruang yang memadai untuk mengoptimalkan seluruh potensi yang dimiliki dan memenuhi secara optimal semua keinginan dan harapannya. Seiring dengan tumbuhnya faham individualisme dan demokrasi, tata masyarakat yang diatur menurut ideology hegemonis seperti ini kemudian dianggap problematic, lalu muncul proses untuk menata ulang masyarakat ke dalam pola hubungan yang lebih egalitarian yang tidak membedakan individu dari latar belakang seks, ras, agama, dan kelas ekonomi. Dalam konteks hubungan gender, modernisasi kemudian tercermin, salah satunya dari perluasan hak perempuan sebagai manusia merdeka dan kesamaan hak yang dimiliki perempuan dalam berbagai aspek kehidupan domestik dan publik, termasuk hak politik, hak pendidikan, hak memperoleh pekerjaan, hak kesehatan reproduksi, dan lain-lain. ${ }^{7}$ Namun, tampaknya itu saja tidak cukup; di samping itu, masih

'T.O. Ihrơmi, 2000, "Hukum, Jender, dan Diskriminasi terhadap Wanita", dalam T.O. Ihromi, dkk (Penyunting), Penghapusan Diskriminasi Terhadap Wanita (Bandung: Penerbit Alumni, 2000), hlm 68.

"Muhadjir Darwin, "Maskulitas: Posisi Laki-laki dalam Masyarakat Patriarkhis", dalam Muhadjir Darwin dan Tukiran (Editor), Menggugat Budaya Patriarkhis (Yogyakarta: Kerjasama PSKK UGM dan Ford Foundation, Yogyakarta, 2001), hlm. 25-26.

'Ibid, hlm. 24-25. 


\section{Gender Bukan Seks}

Nasaruddin Umar mencoba melakukan inventarisasi terhadap apa yang dimaksud dengan gender itu. Dari definisi yang dirumuskan dalam Womens Studies Encyclopedia, oleh Hilary M. Lips, Linda L. Lindsey, H.T. Wilson, Elaine Showalter, dan Kantor Menteri Negara Urusan Peranan Wanita RI. Dari berbagai definisi itu, Nasaruddin Umar menyimpulkan bahwa yang dimaksud dengan gender itu adalah suatu konsep yang digunakan untuk mengidentifikasikan perbedaan laki-laki dan perempuan dilihat dari segi sosial budaya. Gender dalam arti ini mendefinisikan laki-laki dan perempuan dari sudut non-biologis. ${ }^{9}$ Selanjutnya, Nasaruddin Umar menambahkan bahwa gender secara umum digunakan untuk mengidentifikasi perbedaan laki-laki dan perempuan dari segi sosial-budaya. Sementara seks secara umum digunakan untuk mengidentifikasi perbedaan laki-laki dan perempuan dari segi anatomi biologi. ${ }^{10}$
Mansour Faqih" menjelaskan bahwa pengertian jenis kelamin merupakan pensifatan atau pembagian dua jenis kelamin manusia yang ditentukan secara biologis yang melekat pada jenis kelamin tertentu. Misalnya, bahwa manusia jenis laki-laki adalah manusia yang memiliki penis, memiliki jakala (kala menjing) dan memproduksi sperma. Sedangkan perempuan memiliki alat reproduksi seperti rahim dan saluran untuk melahirkan, memproduksi telur, memiliki vagina, dan mempunyai alat menyusui. Alat-alat tersebut secara biologis melekat pada manusia jenis perempuan dan laki-laki selamanya. Artinya, secara biologis alat-alat tersebut tidak bisa dipertukarkan antara alat biologis yang melekat pada laki-laki dan perempuan. Secara permanen tidak berubah dan merupakan ketentuan biologis atau sering dikatakan sebagai ketentuan Tuhan atau kodrat. Sedangkan konsep lainnya adalah konsep gender, yakni suatu sifat yang melekat pada'kaum laki-laki maupun perempuan yang dikonstruksikan secara sosial maupun kultural. Misalnya; bahwa perempuan itu dikenal lemah lembut, cantik, emosional, atau keibuan. Sementara laki-laki dianggap kuat, rasional, jantan, perkasa. Ciri dari sifat itu sendiri merupakan sifat-sifat yang dapat dipertukarkan. Artinya, ada laki-laki yang emosional, lemah lembut, keibuan, sementara

${ }^{8}$ Muhadjir Darwin, "Properda DIY tidak Sensitif Jender", Artikel dalam Surat Kabar Harian Kedaulatan Rakyat, tanggal 8 September 2001.

'Nasaruddin Umar, Argumen Kesetaraan Jender Perspektif Al-Qur'an, Cetakan Il, (Jakarta: Penerbit Paramadina, 2001), hlm. 33-35.

${ }^{10 / b i d, ~ h l m . ~} 35$.

"Mansour Fakih, 2001, Analisis Genderdan Transformasi Sosial, Cetakan Keenam Yogyakarta: Pustaka Pelajar, 2001), hlm. 7-8. 
ada perempuan yang kuat, rasional, perkasa. Perubahan dari sifat-sifat itu dapat terjadi dari waktu ke waktu dan dari suatu tempat ke tempat yang lain.

Perbedaan gender (gender difference) antara laki-laki dan perempuan terbentuk oleh banyak hal, di antaranya dibentuk, disosialisasikan, diperkuat, bahkan dikonstruksikan secara sosial dan atau kultural, melalui ajaran keagamaan, maupun negara. Melalui proses panjang, sosialisasi gender tersebut akhimya dianggap menjadi ketentuan Tuhan - seolah-olah bersifat biologis yang tidak bisa diubah lagi, sehingga perbedaan-perbedaan gender dianggap dan dipahami sebagai kodrat laki-laki dan kodrat perempuan. Sebaliknya, melalui dialektika, konstruksi sosial gender yang tersosialisasi secara evosional dan perlahan-lahan mempengaruhi biologis masing-masing jenis kelamin. Misalnya, karena konstruksi sosial gender, kaum laki-laki harus bersifat kuat dan agresif, maka kaum laki-laki kemudian terlatih dan tersosialisasi serta termotivasi untuk menjadi atau menuju ke sifat gender yang ditentukan oleh suatu masyarakat, yakni secara fisik lebih kuat dan lebih besar. Sebaliknya, karena kaum perempuan harus lemah lembut, maka sejak bayi proses sosialisasi tersebut tidak saja berpengaruh kepada perkembangan emosi dan visi serta ideologi kaum perempuan, tetapi juga mempengaruhi perkembangan fisik dan biologis selanjutnya. Karena proses sosialisasi dan rekonstruksi berlangsung secara mapan dan lama, akhirnya menjadi sulit dibedakan apakah sifat-sifat gendr itu, seperti kaum perempuan lemah lembut dan kaum laki-laki kuat perkasa, dikonstruksi atau dibentuk oleh masyarakat atau kodrat biologis yang ditetapkan oleh Tuhan. Namun, dengan menggunakan pedoman bahwa setiap sifat biasanya melekat pada jenis kelamin tertentu dan sepanjang sifat-sifat tersebut bisa dipertukarkan, maka sifat terebut adalah hasil konstruksi masyarakat dan sama sekali bukanlah kodrat.

Untuk menjernihkan perbedaan antara gender dan seks ini, kiranya tepat apa yang dikemukakan oleh Mansour Fakih bahwa yang menjadi masalah adalah terjadinya kerancuan dan pemutarbalikan makna tentang apa yang disebut seks dan gender. Dewasa ini terjadi peneguhan pemahaman yang 'tidak pada tempatnya di masyarakat, di mana:apa yang sesungguhnya gender, karena pada dasarnya konstruksi sosial justru dianggap sebagai kodrat yang berarti ketentuan biologis atau ketentuan Tuhan. Justru sebagian besar yang dewasa ini sering dianggap atau dinamakan kodrat wanita adalah konstruksi sosial dan kultural atau gender. Misalnya saja, sering diungkapkan bahwa mendidik anak, mengelola, dan merawat kebersihan dan keindahan rumah tangga atau urusan domestik sering dianggap sebagai kodrat wanita. Oleh karena itu, boleh jadi urusan tersebut bisa dilakukan oleh kaum laki-laki, mengingat jenis pekerjaan itu bisa dipertukarkan dan tidak bersifat universal, apa yang sering disebut sebagai kodrat wanita atau takdir Tuhan atas wanita dalam kasus tersebut di atas, sesungguhnya adalah gender. Demikian pula dalam masyarakät kita, ada semacam keyakinan bahwa wanita meskipun sekolah tinggi-tinggi akhirnya juga harus ke dapur. Artinya adalah bahwa wanita tidak boleh lupa akan kodratnya harus pintar memasak. Sehingga, adalah tabu atau belum menjadi wanita atau ibu rumah tangga yang sejati kalau tidak bisa memasak dengan baik. Bahkan, terkadang dapat menjadi pergunjingan 
apabila diketahui wanita atau ibu rumah tangga itu tidak dapat memasak. Dan pada gilirannya, suami yang sering makan di warung atau restoran adalah lambang kekurangharmonisan sebuah rumah tangga. Sekali lagi, wanita harus pintar memasak bukanlah kodrat, karena ia dapat dipertukarkan.

Oleh karena itu, untuk sampai pada pemahaman yang jernih lagi komprehensif tentang gender dan seks perlu dilakukan dekonstruksi dan selanjutnya melakukan rekonstruksi terhadap konsep maskulinitas. Berkaitan dengan maskulinitas ini sangat menarik apa yang dikemukakan oleh Muhadjir Darwin ${ }^{12}$ yang mengatakan bahwa maskulinitas adalah suatu streotype perempuan. Maskulin vs feminin adalah dua kutub sifat yang berlawanan dan membentuk suatu garis lurus yang setiap titiknya menggambarkan derajat kelaki-lakian (maskulinitas) atau keperempuanan (femininitas). Seorang laki-laki yang memiliki karakteristik yang identik dengan streotype maskulin disebut laki-laki maskulin, jika karekteristik tersebut berlebihan disebut laki-laki super maskulin, jika kurang disebut laki-laki kurang maskulin atau laki-laki feminin. Demikian sebaliknya, jika dibaca variasi sifat seorang perempuan.

Streotype maskulinitas dan feminitas mencakup berbagai aspek karakteristik individu, seperti karakter atau kepribadian, perilaku, peranan, okupasi, penampakan fisik, ataupun orientasi seksual. Jadi, misalnya; lakilaki berciri watak yang terbuka, kasar, agresif, dan rasional, smentara perempuan bercirikan tertutup, halus, afektif, dan emosional. Dalam hubungan individu, laki-laki diakui maskulinitasnyajika terlayani oleh perempuan, sementara perempuan terpuaskan feminitasnya jika dapat melayani laki-laki. Dalam hal okupasi pekerjaan yang mengandalkan kekuatan dan keberanian, seperti tentara, sopir, petinju, dan sebagainya disebut sebagai pekerjaan maskulin, sementara pekerjaan yang memerlukan kehalusan, ketelitian, dan perasaan, seperti salon kcantikan, juru masak, menjahit, dan sebagainya, dinamakan pekerjaan feminin. Streotype seperti inilah yang pada gilirannya menciptakan hubungan yang bias antara lakilaki dan perempuan, hegemoni laki-laki atas perempuan dianggap sebagai sesuatu yang kodrati. Menjadi jelas pula disini bahwa tanpa melakukan dekonstruksi dan rekonstruksi terhadap konsep maskulinitas, di samping suciah barang tentu dekonstruksi konsep feminitas, hubungan laki-laki dan perempuan yang egalitarian sulit terwujud.

Salah satu streotype maskulinitas yang penting untuk didekonstruksi adalah konsep fathemood (kebapakan). Susan W. Murray sebagaimana yang dikutip Muhadjir Darwin menemukan fenomena di masyarakat Barat bahwa pekerjaan merawat anak dianggap sebagai pekerjaan yang sarat gender, atau lebih spesifik lagi sebagai pekerjaan yang sangat feminin. Kemudian, keinginan ayah untuk merawat anak cenderung dicurigai, bahkan dianggap sebagai perilaku patologis. Sementara itu, Ralp LaRossa menemukan kecenderungan baru laki-laki Barat saat ini untuk lebih memperhatikan perawatan anak dan menganggap hal demikian sebagai bentuk modernisasi. LaRossa menyebut

12Muhadjir Darwin, op. cit, hIm. 27-29. 
kecenderungan ini sebagai masculine domesticity atau domestic masculinity dan di bagian lain disebut sebagai proses fatherhood evolution. Proses ini mengarah kepada pembagian kerja di sektor domestik yang lebih seimbang antara laki-laki dan perempuan. Brod juga menggugat kecenderungan mengabaikan fatherhood sebagai streotype maskulinitas. la menuturkan secara historis bagaimana pada keluarga Barat awal abad ke 19, peranan fatherhood dari suami lebih menonjol dibandingkan dengan peranan motherhood seorang isteri. Peranan fatherhood dari suami ini kemudian menurun seiring dengan proses industrialisasi. Lebih lanjut Brod mengatakan bahwa dominasi laki-laki di sektor publik merupakan pelarian laki-laki karena mereka mengalami marginalisasi di sektor domestik. Lalu dia mempertanyakan secara kritis, mengapa statistik hanya menyediakan angka tentang proporsi ibu rumah tangga yang bekerja, tetapi tidak pemah ada angka lakilaki pekeja yang menjalankan fungsi fatherhood.

Uraian di atas, menurut Muhadjir Darwin, pada dasarnya ingin menegaskan bahwa streotype meskulinitas dapat berarti pengambilan peranan yang seimbang dari laki-laki di sektor domestik. Marginalisasi lakilaki di sektor domestik justru harus dilihat sebagai fenomena sosial yang patologis. Rekonstruksi yang demikian penting untuk menciptakan hubungan laki-laki dan perempuan yang lebih egalitarian.

\section{Contoh-contoh Hukum yang Bias Gender}

Hukum di sini diartikan sebagai hukum positif atau hukum tertulis. Oleh karena itu, contoh-contoh yang dimaksud adalah rumusan-rumusan pasal yang terdapat di berbagai peraturan perundang-undangan yang dianggap bias gender. Dari berbagai pendapat tersebut di atas, maka dapat dikemukakan bahwa pada dasarnya perbedaan gender tidaklah begitu masalah sepanjang tidak melahirkan ketiadakadilan gender (gender inequalities). Namun, dalam realitasnya yang terjadi ternyata perbedaan gender telah melahirkan sejumlah ketidakadilan baik bagi kaum laki-laki, terutama terhadap kaum perempuan. Berikut dikemukakan beberapa ketentuan hukum yang mencerminkan ketidakadilan gender.

1. Pasal 31 ayat (1) Undang-undang Nomor 1 Tahun 1974 tentang Perkawinan (UU Perkawinan) menyebufkan "Suami adalah kepala keluarga dan isteri adalah ibu rumah tangga".

Ketentuan ini sangat jelas menempatkan perempuan aktif di sektor domestik; memasak, membersihkan rumah, mengasuh anak, dengan kata lain perempuan yang telah bersuami otomatis telah meneken kontrak untuk mengabiskan waktunya di rumah. Implikasi lebih lanjut terhadap ketentuan ini adalah telah melakukan pembenaran terhadap konstruksi sosial dan budaya yang sesungguhnya sangat sarat dengan perlakuan tidak adil terhadap perempuan. Di samping itu, telah membentuk suatu pandangan atau bahkan keyakinan bahwa mengatur urusan rumah tangga, mengasuh anak, memasak, dan sejenisnya adalah tugas kodrati kaum perempuan, sehingga sejak awal mereka harus dipersiapkan untuk memiliki berbagai keterampilan itu. 
2. Pasal 34 UU Perkawinan:

(1) Suami wajib melindungi isterinya dan memberikan segala sesuatu keperluan hidup berumah tangga sesuai kemampuannya;

(2) Isteri wajib mengatur urusan rumah tangga sebaik-baiknya.

Ketentuan Pasal 34 ayat (1) tersebut semakin mempertegas ketentuan Pasal 31 ayat (1) di atas. Laki-laki ditempatkan sebagai makhluk yang bertanggung jawab atas ekonomi keluarga. Sebaliknya, wanita dianggap tidak memiliki kemampuan untuk mencari nafkah, untuk mencukupi kebutuhan hidup keluarga termasuk anak-anak. Namun, ayat tersebut menjadi rancu dengan adanya kata-kata "sesuai dengan kemampuannya". Anak kalimat seperti ini memiliki implikasi bahwa isteri tidak boleh menuntut kepada suami, meskipun itu sesungguhnya masih dalam ukurang layak. Artinya, isteri harus bersifat nrimo berapapun yang diberikan dan harus mampu mengelolanya sehingga menjadi cukup. Ini adalah sebuah pasal yang menempatkan isteri pada posisi yang dilematis.

Sementara itu, pada ayat (2) justru isteri diwajibkan untuk mengatur rumah tangga dengan sebaik-baiknya. Padahal suami dalam memberikan segala sesuatu keperluan hidup berumah tangga sesuai dengan kemampuan. Sesuai dengan kemampuannya ini sungguh sangat relatif, tidak memiliki standar yang rasional. Tetapi, hanya semata-mata didasarkan kepada kemampuan suami, tidak didasarkan kepada realitas besarnya keperluan hidup keluarga. Sehingga, ketentuan pasal ini dapat dijadikan justifikasi bagi suami yang sesungguhnya kurang bertanggung jawab dengan dalih bahwa mampunya hanya segini.

Di samping itu, ketentuan tersebut juga telah menempatkan laki-laki sebagai makhluk yang superior (serba kuat), sedangkan perempuan sebagai makhluk yang inferior (serba lemah), sehingga harus dilindungi. Isteri tidak mungkin mampu untuk melindungi dirinya sendiri tanpa bantuan suaminya. termasuk untuk mencari nafkah dalam rangka mencukupi kebutuhan hidupnya. Oleh karenanya, sebagai rasa terimakasihnya terhadap suaminya, maka ia harus mengurus rumah tangga sebaik-baiknya. Padahal dalam realitasnya, banyak suami yang lemah, dan tidak sedikit justru yang mencukupi ekonomi rumah tangga adalah isteri. Sejarah juga telah menunjukkan Khatijah isteri nabi Muhammad menduduki tempat yang penting dalam sejarah Islam, karena sangat berarti bagi Muhammad. Kekayaannya membebaskan Muhammad dari mencari nafkah, sehingga memungkinkannya menempuh kehidupan kontempelasi sebelum diangkat menjadi seorang nabi. Dukungan dan kepercayaan Khatijah sangat berarti baginya dalam perjuangannya mendakwahkan Islam. ${ }^{13}$

\section{Pasal 285 KUHPidana: "Barangsiapa dengan kekerasan atau ancaman kekerasan memaksa seorang wanita bersetubuh dengan dia di luar pernikahan.}

\footnotetext{
${ }^{13}$ Leila Ahmed, 1992, Women and Gender in Islam: Historical Roots of a Modem Debate (New Haven \& London: Yale University Press, 1992), him. 46-47.
} 
diancam karena melakukan perkosaan, dengan pidana penjara paling lama dua belas tahun"

Ketentuan pasal tersebut telah mengkonstruksikan bahwa pemerkosa atau pelaku pemerkosaaan selalu berjenis kelamin laki-laki. Sedangkan korban pemerkosaan selalu berjenis kelamin perempuan. Padahal kisah nabi Yusuf AS adalah sebuah bukti sejarah yang sangat autentik bahwa laki-laki juga dapat dalam posisi sebagai korban (percobaan) pemerkosaan dan perempuan justru pada posisi pelaku (percobaan) pemerkosaan.

Bias gender lainnya yang terdapat dalam ketentuan pasal tersebut adalah bahwa pasal itu telah menempatkan isteri harus selalu siap melayani suami, meskipun ia dalam keadaan tidak ataun kurang fit. Suami dapat memaksa isterinya untuk melayani nafsunya ibarat iklan coca cola "kapan saja, dimana saja". Karena, berdasarkan ketentuan pasal tersebut isteri tidak dapat mengadukan suaminya dengan tuduhan telah melakukan semacam "marital rapew.

\section{Pasal 346 KUHPidana: "Seorang wanita} yang sengaja menggugurkan atau mematikan kandungannya atau menyuruh orang lain melakukan hal itu, diancam dengan ancaman pidana penjara paling lama empat tahun"

Ketentuan ini disebut juga sebagai larangan untuk melakukan aborsi. Namun, ketentuan ini juga sekaligus menunjukkan bahwa wanita tidak mempunyai hak atas tubuhnya sendiri, tidak mempunyai otonomi atas dirinya sendiri. Meskipun kehamilan itu bukan atas kehendaknya, sebagai buah dari tindakan pemerkosaan yang dilakuka terhadapnya. Padahal, begitu masyarakat tah kalau dia hamil tanpa mempunyai suami, $h_{i}$ itu telah menjadikan aib tersendiri bagi diriny sendiri dan keluarganya. Begitu juga, ketik anaknya lahir, bukan saja dia sesungguhny belum siap untuk memiliki anak. Tetapi jug: dia harus menanggung semua hal yan berkaitan dengan masa depan anak itu.

Di samping itu, adakalanya meman kehamilan itu pada awalnya adalah sesuat yang dikehendaki. Namun, hal itu hasil rayua seorang laki-laki yang sebut saja sebag: pacamya yang mengatakan akan bertanggun jawab apabila dari hubungan suka sama suk itu dirinya hamil. Setelah dia hamil, temyat pacamya tadi tidak mau menikahinya denga dalih macam-macam. Di tengah kebingunga seperti itu, si wanita berdasarkan pasal it। apabila melakukan tindakan aborsi, padahe hal itu dia lakukan tidak berdiri sendiri. Namur hanya wanita saja yang harus menanggun! hukumannya. Sementara si laki-laki tadi sam: sekali tidak dapat dijerat secara hukum Ketentuan tersebut telah menempatkan posis wanita pada posisi yang sangat dilematis, yakr maju kena mundur kena, artinya; membiarka kehamilan otomatis mendatangkan aib sedangkan menggugurkan harus berhadapal dengan hukum.

5. Pasal 108 KUHPerdata: "Sang isteri sekalipun dia kawin di luar harta bersami atau dengan harta benda terpisah tidal dapat menghibahkan, memindahtangankar menggadaikan, memperoleh apapun baik secara Cuma-Cuma maupun dengal beban, tanpa bantuan suami dalam akti atau izin tertulis" 
Ketentuan tersebut jelas sekali menentukan bahwa yang paling berkuasa atau memiliki otoritas atas pengurusan harta dalam rumah tangga adalah laki-laki (suami), sekalipun harta itu merupakan hasil jerih payah dari sang isteri. Isteri sama sekali tidak memiliki otoritas yang otonom atas pemanfatan harta yang dimilikinya sebelum mendapatkan persetujuan dari suaminya. Dengan kata lain, ketentuan ini telah memberikan stempel hukum bagi wanita yang bersuami tidak cakap untuk melakukan perbuatan hukum secara otonom.

6. Pasal 110 KUHPerdata: "Isteri tidak boleh tampil dalam pengadilan tanpa bantuan suaminya, meskipun dia kawin tidak dengan harta besama, atau dengan harta terpisah, atau meskipun dia secara mendiri menjalankan pekerjaan bebas"

Ketentuan ini juga menempatkan kaum wanita yang bersuami sebagai kaum yang paling tidak secara hukum adalah lemah. Sehingga, mempertegas posisi wanita sebagai makhluk yang tidak otonom dan makhluk yang tidak mampu melakukan perbuatan hukum. Apalagi untuk secara otonom tampil di depan pengadilan untuk memberikan kesaksian, memperjuangkan hak-haknya, dan sebagainya.

7. Pasal 97 ayat (1) Undang-undang Nomor 25 Tahun 1997 tentang Ketenagakejaan, yang menyebutkan:

Setiap pengusaha dilarang memperkejakan wanita untuk melakukan pekerjaan:

a. di dalam tambang di bawah tanah, lubang di bawah permukaan tanah, tempat mengambil mineral logam_dan bahan-bahan galian lainnya dalam lubang atau terowongan di bawah tanah termasuk dalam air; b. pada tempat kerja yang dapat membahayakan. kesusilaan, keselamatan, kesehatan, dan yang tak sesuai dengan kodrat; harkat, dan martabat pekerja wanita;

c. pada waktu tertentu malam hari.

Ketentuan tersebutimüngkin saja dimaksudkan untuk memberikan períidungan kerja terijadap kaum perempuan; namun tanpa disadari justru terjebak pada bias gender. Ketentuan huruf a telah memposisikan wanita sebagai makhluk yang lemah, tidak mampu untuk melakukan pekerjaan itu. Pékerjaan itu hanya cocok bagi kaum laki-laki. Dengan kata lain, ketentuan tersebut telah melakukan konstruksi yuridis bahwa jenis-jenis pekerjaan tersebut adalah pekejjaan yang secara kodrati hanya dapat atau cocok dilakukan oleh kaum lakilaki; oleh karena itu secara kodrati pula kaum wanita tidak dapat atau cocok untuk melakukan perkerjaan itu.

Sedangkan pada huruf $b$, apabila dipahami secara terbalik, maka tidak ada jenis pekerjaan yang dapat membahayakan kesusilaan, keselamatan, kesehatan, dan yang tak sesuai kodrat, harkat, dan martabat pekerja laki-laki. Dengan kata lain, wanita memiliki berbagai keterbatasan. Oleh karena itu, di dalam mencari pekerjaan, maka ia harus mempertimbangkan jenis pekerjaan itu agar tidak membahayakan kesusilaan, keselamatan, kesehatan, dan sesuai dengan kodrat, harkat, dan martabatnya sebagai wanita.

Sementara itu, ketentuan huruf $c$ yang melakukan pelarangan perempuan bekerja pada malam hari juga sangat sarat dengan muatan bias gender. Karena, bisa jadi alasannya bersifat klasik, yakni; pada malam hari, terutama kaum perempuan yang sudah bersuami apalagi telah mempunyai anak. 
Maka, otomatis apabila ia bekerja pada malam hari dianggap dapat melalaikan kewajibannya untuk melayani anak sekaligus sang suami. Sementara, apabila sang suami yang bekerja pada malam hari tidak dapat dianggap melakukan hal yang sama. Karena, suami dianggap tidak mempunyai kewajiban untuk melayani sang isteri, apalagi untuk mengurus anak pada malam hari, menyiapkan berbagai keperluannya pada pagi hari, dan sebagainya.

8. Pasal 49 ayat (1) Undang-undang Nomor 39 Tahun 1999 tentang Hak Asasi Manusia, yang menyebutkan: "Wanita berhak untuk memilih, dipilih, diangkat dalam pekerjaan, jabatan, dan profesi sesuai dengan persyaratan dan peraturan perundang. undangan"

Ketentuan pasal tersebut dapat mempunyai konotasi bahwa laki-laki untuk memperoleh hal itu tidak memerlukan persyaratan. Dengan kata lain, semua laki-laki otomatis dapat memperoleh hak-hak tersebut. Tidaklah demikian halnya dengn wanita yang harus memenuhi persyaratan yang ditentukan. Apabila tidak memenuhi pesyaratan yang ditentukan, maka dengan sendirinya tidak memperoleh hak-hak tersebut.

Ketentuan tersebut jelas sangat bias gender, karena telah menempatkan wanita pada posisi yang dirugikan. Kaum laki-laki untuk memperoleh hak-hak tersebut tidak memerlukan persyaratan, sementara kaum wanita untuk memperoleh hak-hak tersebut diharuskan memenuhi persyaratan yang ditentukan.
Simpulan.

Persoalan gender adalah persoala keadilan. Hukum sudah seharusny menempatkan posisi perempuan dan laki-lal pada posisi yang setara, pada posisi yan sama. Banyak peraturan perundanc undangan yang masih menempatkan posi! perempuan tidak sama atau tidak setar dengan posisi kaum laki-laki. Dan pada umur penempatan yang tidak sama atau setara it lebih banyak menguntungkan posisi kaum lak laki. Sebagaimana bunyi rumusan beberap peraturan perundang-undangan yang tela dibahas di atas.

Oleh karena itu, sudah saatnya, ketentua peraturan perundang-undangan yang bia gender tersebut, yang menempatkan posis laki-laki dan perempuan tidak setara ata tidak sama itu dicabut. Setelah itu, digantikal dengan peraturan perundang-undangan yan! adil yang menempatkan posisi perempual dan laki-laki dalam kesetaraan.

\section{Daftar Pustaka}

Irwan Abdullah. Seks, Gender, dan Reproduks Kekuasaan. Yogyakarta: Tarawan! Press, 2001.

Ivan Illich. Matinya Gender. Cetakan Ketiga Yogyakarta: Penerbit Pustaka Pelajal 2001.

Leila Ahmed. Women and Gender in Islam Historical Roots of a Modem Debate New \& London: Yale University Press 1992.

Nasruddin Umar. Argumen Kesetaraan Gen der Perspektif Al-Qur'an. Jakarta Penerbit Paramadiana, 2001. 
Mansour Fakih. Analisis Gender dan Transformasi Sosial. Cetakan Keenam. Yogyakarta: Pustaka Pelajar, 2001.

Moh Mahfud MD. Politik Hukum di Indonesia. Jakarta: Kerjasama UII Press dan LP3ES, 1998.

Muhadjir Darwin dan Tukiran (Editor). Menggugat Budaya Patriarkhi. Yogyakarta: Kerjasama PPK UGM dengan Ford Foundation, 2001.

. "Properda DIY tidak Sensitif Jender". Artikel dalam Surat Kabar Harian Kedaulatan Rakyat, tanggal 8 September 2001.
Smita Notosusanto dan E. Kristi Purwandari (Penyunting). Perempuan dan Pemberdayaan. Jakarta: Diterbitkan oleh Program Studi Kajian Wanita Program Pasca Sarjana UI Bekerjasama dengan Kompas dan Penerbit Obor, 1997. . dkk (Penyunting). 2000, Penghapusan Diskriminasiterhadap Wanita. Bandung: Penerbit Alumni, 2000. . Kajian Wanita dalam Pembangunan. Jakarta: Yayasan Obor Indonesia, 1995. 